\title{
New Perspectives on Retranslation: The Case of Iran ${ }^{1}$
}

\section{Samira Saeedi \\ The University of Melbourne}

This paper explores retranslation in contemporary Iran (1979-2019). Retranslation, following Tahir Gürçağlar, is defined here as "the act of translating a work that has previously been translated into the same language, or the result of such an act, i.e. the retranslated text"(232). In Iran, Western classics, best-sellers and award-winning books are often retranslated multiple times. Almost one-hundred translations of George Orwell's Animal Farm and forty different translations of 1984 are available on the Iranian book market. The more recently published Becoming, by Michelle Obama (2018) has had twenty-six different translations within a year of its publication in 2018. This seems to be the reason why Iranian journalists view retranslation as a "competition" (see Ghane).

This "distinctive feature" of the Persian translation tradition, as Azadibougar and HaddadianMoghaddam (157) call it, sparked my interest in the following questions: Why is retranslation common in Iran? What advantages do retranslations yield for Iranian translators and publishers? What leads readers to select one retranslation over others? This paper argues that retranslation in Iran is a significant and often profitable social phenomenon.

For this study, I conducted interviews with ten Iranian literary translators and six publishers in Tehran, Iran, all of whom were highly recognized agents of translation. ${ }^{2}$ This approach enabled me to offer a reliable snapshot of the reasons behind retranslation in Iran. This is followed by the exemplary case study of the retranslation of Animal Farm (hereafter AF).

\section{Discourse around Retranslation}

In contemporary Iran, the number of (re)translations is sharply increasing (Saeedi and Karimi Behbahani). The literature on retranslation is extensive, focusing commonly on comparative textual and occasionally paratextual analysis. For instance, a textual analysis of three retranslations of Pride and Prejudice (Austen) tested the validity of the Retranslation Hypothesis (Vahid Dastjerdi and Mohammadi), while a more recent study examines visual representations of AF by comparing three retranslations against their start text (Amirdabbaghian and Shunmugam). ${ }^{3}$ In his book, Literary

\footnotetext{
1 The present study is based on my PhD dissertation The Role of Translators in Contemporary Iran: New Perspectives on Collaboration, Retranslation and Visibility submitted to the University of Melbourne (2016-2020).

I am grateful to the anonymous reviewers for their suggestions. I am also indebted to Andrea Rizzi for reading versions of my article. All translations from Persian into English are mine, unless otherwise stated.

2 To conduct the interviews, I obtained the ethics approval from the Faculty of Arts Human Ethics Advisory Group (HEAG), The University of Melbourne (approval number: 1749018).

3 Retranslation Hypothesis assumes that "later translations tend to be closer to the source text" (Chesterman 8). Throughout this paper, to follow Pym, I use "start text" as the text we translate from to include "views of translation" that assume texts are "made up of translations" and "reworked fragments of previous texts" (1-2).
} 
Translation in Modern Iran: A Sociological Study, Esmaeil Haddadian-Moghaddam effectively engages with Persian retranslations of English novels such as Pride and Prejudice (Austen) and reveals the underlying motivations of their translators and publishers.

Against this academic backdrop however, Iranian translation scholars, critics, reviewers, and journalists predominantly consider retranslation a cultural crisis in the public discourse. ${ }^{4}$ For instance, in an online daily newspaper, Pirouzeh Rohaniyoun, an Iranian author and journalist, believes that amateur translators take on retranslation in a quest for financial gain and prestige (Rohaniyoun). In her view, having one's name on an award-winning book does bring a translator prestige and financial gain, but she remarks that retranslations by amateur translators are conducted in haste and are of low quality (Rohaniyoun). Quoting iconic Iranian translators Najaf Daryabandari and Media Kashigar, Rohaniyoun suggests that skilled translators recommend retranslations only when a more fluent translation is needed. In an interview with Islamic Republic News Agency (IRNA), Iranian translation scholar Karimi Behbahani stated that he considers retranslation a profit-driven practice, especially for publishers. Like Rohaniyoun, he holds that rather than aiming to offer a more accurate translation, retranslation is a socially motivated practice for amateur translators (Karimi Behbahani). Contextual factors such as the lack of clear commitment to national and international copyright conventions, for example the Berne convention, are recognized as a key reason for the increasing number of retranslations in Iran. ${ }^{5}$

The most interesting point emerging from the above-mentioned articles is the sharp distinction between how the intentions of amateur and non-amateur translators are viewed. On the one hand, retranslations performed by amateur translators, in which copies of previous translations are republished with minor or no revisions, are deemed to be a profit-driven practice and seem to be distrusted by readers. On the other hand, retranslations carried out by established Iranian translators, who are more trustworthy agents of translation, are considered valuable cultural contributions. Following Chesterman, I define trust here broadly as the belief that someone or something meets the expectations of other parties (Memes of Translation 178). Trustworthiness of translation agents is the point of departure in this paper. To the best of my knowledge, no previous study has engaged with the relevance of translators' professional status and socio-cultural and economic motives as well as the reception of retranslations in Iran. My study aims to fill this gap.

\footnotetext{
4 This issue is addressed in different news broadcasting and interviews with experts, translators and publishers. Here are few links to news on the issue of retranslations. On retranslations of Dostoyevsky see: http://traductologie.blogfa.com/category/12 (access date: 10 September 2018).

5 Although Iran is not a member of any international copyright conventions, publishers more commonly tend to get permission from the start text's author for translating their works. Iran has two national copyright laws: the copyright law of 1969 [Haqq-e Mo'allef] and the Law concerning the translation and reproduction of books, publications, and audio recordings [Qānūn-e tarjama wa takțīr-e kotob wa našrīyāt wa ātāa șawtī]. See http://www.iranicaonline.org/articles/copyright (access date: 30 October 2019).

The Berne Convention protects producers' literary, artistic and intellectual rights, ratified in Berne, 1886. Retrieved from http://www.wipo.int/treaties/en/ip/berne/ (access date: 10 September 2018).
} 
In this paper I use the terms 'amateur' and 'early-career' translators to describe translators who have never translated before, or who have translated only one title before moving into retranslating. As I discuss below, these two categories usually collaborate with newly established publishers and are less recognized members of the Iranian literary translation field. I also use the terms 'mid-career' and 'senior' translator to describe translators who have introduced new foreign authors by translating more than two new titles into Persian. Mid-career and senior translators usually collaborate with highbrow publishers, and the participants of this study fall into these groups.

\section{Retranslation beyond the Text}

This article benefits immensely from recent contributions to our understanding of literary retranslation. ${ }^{6}$ Particularly relevant to my study is Sharon Deane-Cox's work on retranslation in the history of English and French literature. Drawing on Pierre Bourdieu's literary practice theory, DeaneCox investigates the role of translators and publishers in retranslations of Gustave Flaubert's Madame Bovary and George Sand's La Mare au Diable between the $19^{\text {th }}$ and $20^{\text {th }}$ centuries. She does so by utilizing the novels' paratextual materials to illuminate the underlying motivations for retranslations. DeaneCox has shown that retranslation is a "complex" practice and it is "as much a socially and a culturally embedded phenomenon as it is a textualized one" (189-190). I take a similar approach to my study of retranslation in contemporary Iran.

This article, therefore, situates itself within the paradigm of sociology of translation due to its emphasis on the role of translators and publishers (hereafter 'agents') in retranslations of literary works (see Wolf). The choice of focusing on the role of agents is because active retranslations are common in Iran, in particular among amateur and early-career translators. Active retranslation, according to Anthony Pym, refers to retranslation in "virtually the same cultural location and generation" that is produced in a state of rivalry (Method in Translation History 82-83). Mid-career and senior translators are comparatively inclined towards passive retranslations: that is, to retranslate when there is "likely to be little active rivalry between different versions" (82). Hence, in this context, the strong presence of active retranslations in Iran invites translation scholars to explore the role of agents and the possible motives behind retranslation. Here I use Pierre Bourdieu's concepts of capital and field to discern translators' and publishers' motivations and agency in what I term the literary translation field of Iran; Inspired by Bourdieu's definition of literary field (143), 'field' is defined here as the social space in which translators and publishers strategically act to define their status, and 'capital' as both the economic and non-economic benefits of retranslation for the translators and publishers (The Forms of Capital 81-93).

\footnotetext{
${ }^{6}$ For revisiting the Retranslation Hypothesis see: Paloposki and Koskinen, Deane-Cox. For researching retranslation see also: Tahir-Gürçaglar. For narrative theory and retranslation see: Brownlie. On translators' voice in retranslation see the Target special issue edited by Alvstad and Rosa. On collaboration and retranslation see: Bistué, Rizzi. For retranslation of children literature see Pokoron.
} 


\section{Method}

This case study draws on interviews and paratextual analysis to answer the questions outlined above. I conducted sixteen semi-structured interviews with ten Iranian literary translators and six publishers to explore the process of commissioning translators, the incentives for retranslation, and the translators and publishers' perspectives towards retranslation. This is because the sole use of paratextual materials would "reveal little, if any, information from behind the scenes" of retranslation commissioning process (Deane-Cox 26). The knowledge and the experiences of Iranian translators and publishers are a crucial source of data to highlight the motives underpinning retranslation.

Moreover, because paratextual materials offer "evidence for the type and extent of interactions between the (re)translations" (Deane-Cox 34), I elected to examine the paratextual materials of four of AF's retranslations. This allows to recognize how translators use retranslation to assert their trustworthiness over past translations. Due to the rivalry in the literary translation field of Iran, retranslations tend to challenge previous translations and translators. Using paratextual elements (pictures, notes, visual cues), translators and publishers try to convince readers that their new retranslation is trustworthy. Amateur translators in particular use a variety of strategies to introduce their retranslation as the latest, most reliable version of the start text.

To reveal the strategies of trust building, I apply a recently introduced concept of trust-signalling to the study of retranslations: "Signalling is persuasion: a rhetorical and psychological strategy employed to reassure or convince an audience" (Rizzi et al. 19). Translators and publishers use trustsignalling markers as a device to convince readers that they are trustworthy agents of translation, either to gain benefits or avoid accusations of copying/paraphrasing previous translations.

\section{Retranslation: Risk and Reward}

In the context of Iran, retranslation projects tend to be publisher-initiated. Five of the six publishers I interviewed have commissioned translators to carry out retranslations (July-September 2017, Tehran). The interviewed publishers usually ruled out the financial motivation for retranslation. This is not new. Haddadian-Moghaddam explains there is "a strong tendency among Iranian literary translators and publishers to subscribe to the "love of literature" generally as their incentive for choosing to be a literary translator and publisher (182). However, this 'love of literature' is only one of the several expressions of the social and economic motivations I examine here. The perceived inadequacy of previous translations is the main incentive and justification for publishers to offer a new translation. The inadequacy is normally attributed to the archaism of the Persian language used in earlier translations, and the alleged incompetence of past translators. Therefore, to support their claim and justify their decisions for retranslation, they commission senior or mid-career translators. 
The Iranian publishing house, Ofoq Publishers, tends to retranslate world literature classics. ${ }^{7}$ Being recognized as a major publisher of authors such as Hermann Hesse increases the social prestige of the publisher in the literary translation field. ${ }^{8}$ I asked Samin Nabipour, the director of international affairs at Ofoq Publishers, why they had decided to commission translators to retranslate the world's classics under a series titled '[author's name] heritage'. She responded:

$$
\begin{aligned}
& \text { هم بعد /قتصادى دارد هم بعل يرستيزو هم مجموعه ما راكامل ميكنل. ما به /ينكه ميراث }
\end{aligned}
$$

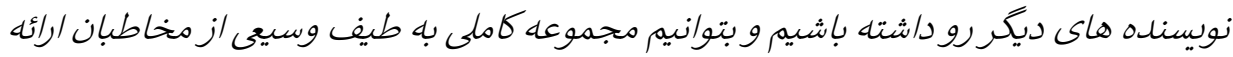

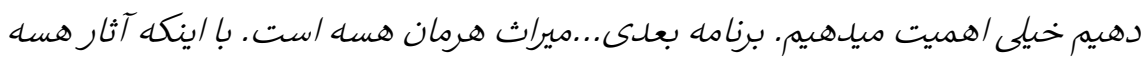

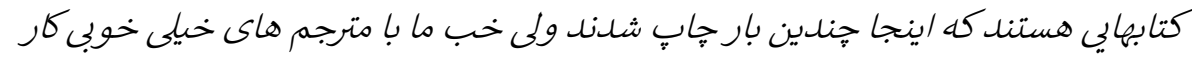

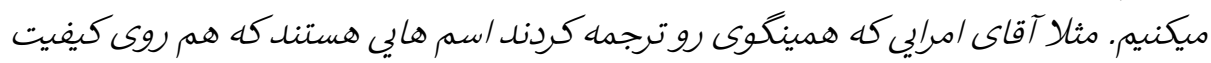



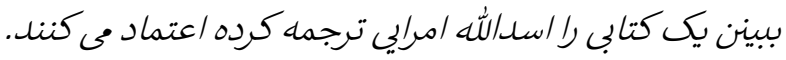

It is profitable, prestigious, and enriches our collection as well. Our prime concern is to offer a rich collection of other authors' heritage to a wide range of readers. We are planning to retranslate Hermann Hesse's heritage. Although they have previously been translated several times, we are commissioning great translators [to retranslate them]. For instance, Asadollah Amraee [re]translated Hemingway's heritage [for us]; his name not only guarantees the quality of translation but it also affects the reception of the text ... I mean, when readers see that Amraee has [re]translated the book, they trust the translation. (Nabipour)

The combination of a renowned author and a famous translator explains the act of retranslation and signals trust. Ofoq Publishers secures the success of new translations of a text not only by the strategic choice of the first authors and their works, but also by commissioning senior translators. The choice of such translators signals that the new translation is a reliable one. In this case, Asadollah Amraee's name, on the front cover of the novel, aims to convince readers of the quality of the translated text.

My interview with Amraee confirms the impact of a translator's professional background not only on publishers' decisions for retranslating books but also on the reception of a retranslation (17 August 2017, Tehran). He told me about an occasion where he met a young translator and they reckoned they were both translating the same book. Amraee says that "لحظه ديدمكه جاخورد. بعلكفتم

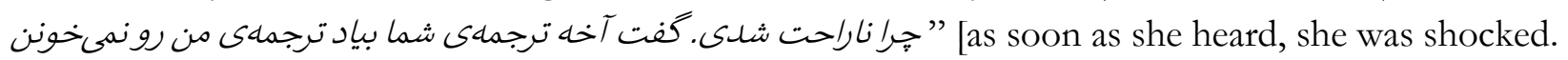
I asked her the reason, she said, 'no one will read my translation while yours is on the market']

\footnotetext{
${ }^{7}$ I conducted this interview with Samin Nabipour, Ofoq Publisher's director of international affairs, on 16 July 2017, Tehran. Ofoq Publishers tend to purchase copyright for their translations.

${ }^{8}$ Hermann Karl Hesse (1877-1962) is a celebrated German-Swiss novelist and the winner of the 1946 Nobel Prize in Literature.
} 
(Amraee). These statements show how investing in trusted translators can grant publishers a competitive edge against their competition in the translation of a given text.

Similar strategies are employed by other publishers to reap the benefits of retranslation and reinforce their trustworthy position for themselves in the literary translation field. Mohammadreza Arbabi, publisher and the director of Translators and Interpreters Association of Tehran (TIAT), says: " [I would publish a retranslation if I [could] commission a great translator to retranslate a famous work] (Arbabi). Arbabi's emphasis is also on commissioning a trustworthy senior translator who has a successful track record. This seems to be a fair justification for retranslation.

Former director of Hermes publishing house, Lotfollah Saghravani, justifies his decision for commissioning a retranslation of Albert Camus' L'Étranger directly from French, and Hermes' plan to market the retranslation of Victor Hugo's Les Misérables, by stressing that the translator-Mohammad

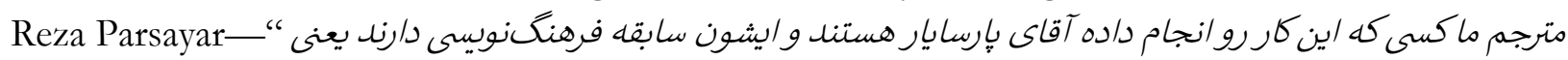
[is a lexicographer and ... has compiled the most recent French-Persian dictionary] (Saghravani). Although Parsayar is a highly competent and educated translator, he is less recognized in the literary translation field, so his background is offered as evidence that the retranslation is trustworthy. Saghravani clarifies that his motivation is educational, as he believes retranslation of world classics from their original language is necessary for the Iranian book market:

$$
\begin{aligned}
& \text { ما ريسك كرديم و روى رمان بينوايان دوهنار و يإنصل صفحه اى سرمايه كنارى كرديم...جهون }
\end{aligned}
$$

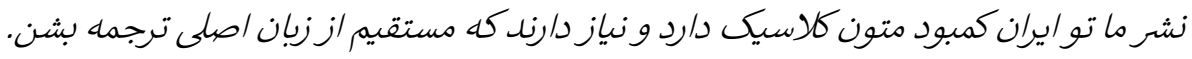

We took the risk and invested in a retranslation of Les Misérables, a twothousand-five-hundred-page novel ... as Iran's book market needs the world classics to be translated directly from their original languages .... (Saghravani)

This statement also reveals how retranslations of certain works are advantageous to a social context and how retranslation allows the agents of translation to intellectually play an influential role in the Iranian book market, in particular when they are trusted agents of the literary translation field. Therefore, gain of cultural capital seems to encourage the production of retranslations.

Leila Hosseinkhani, the director of Agah Publishing House, while ruling out pursuing economic gain through publishing retranslations, states:

$$
\begin{aligned}
& \text { بازترجمه بإى سود /قتصادى نيست، بايد ببينيم كه آيا ضرورتش بوده يا /ينكه ما اين نياز رو }
\end{aligned}
$$

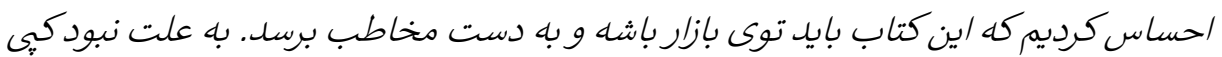

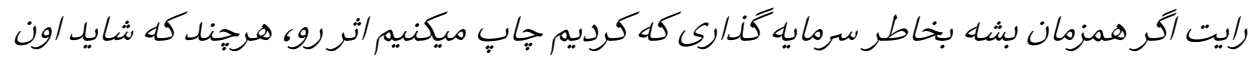

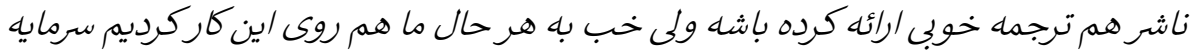

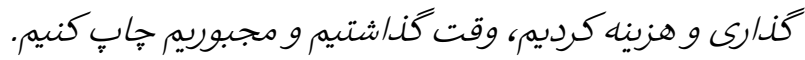


Retranslation is not for economic gains. There should be a need for retranslating a work, or we should feel that the book must be available on the market and accessible to readers. However, due to the lack of copyright laws, in the case of parallel translations, we have no choice but to publish our translations, as we have already invested in the translation project, even if another translation is released by a recognized publisher or translator. (Hosseinkhani)

Hosseinkhani, similar to Saghravani, addresses the cultural urge for retranslation of certain books. She rightly addresses that sometimes translations are released simultaneously in the absence of firm international copyright laws. This sheds light on one of the financial risks of retranslations.

For mid-career and senior translators - those who have translated two or more new titles - the risks of retranslation outweigh its benefits. Retranslators, in particular if they are amateur or earlycareer translators, tend to be perceived as imitators and followers of the first translator and their works are compared to earlier translations by readers (Meftahi). This is the reason why some translators claim that they were unaware of other translations and others express regret for engaging in retranslation or feel they need to justify the reason why they retranslated a book. This is mainly due to the negative discourse around retranslations that label retranslation as a profit-driven praxis. From my interviews, it seems that mid-career translators believe that by retranslating, they put their symbolic capital at risk. Maryam Meftahi, a mid-career translator, for instance, expresses regret at having performed retranslations, and stresses that she will not perform them in future.

$$
\begin{aligned}
& \text { بر اساس تجريه اى كه داشتم تصميم كرفتم ديكر رمانى راكه قبلا ترجمه شله ترجمه نكنم. حتى }
\end{aligned}
$$

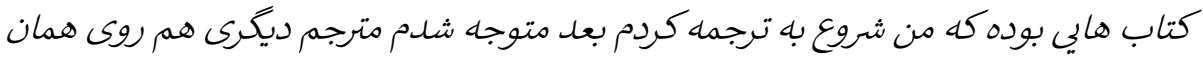





After my first experience of retranslating a book, I decided not to retranslate any novels in the future. There were books I put aside in the process of translation as soon as I heard another translator was working on it ... after retranslating Khaled Hosseini's [The Kite Runner], I realized that I should give priority to introducing new authors and new books to Iranian readership. $\left(\right.$ Meftahi) ${ }^{9}$

The reason she prefers to introduce new authors and works seems to be that it would allow her to gain a leading position in the literary translation field. Meftahi successfully introduced Jojo Moyes' books to Iranian readers. ${ }^{10}$ After her success, many amateur translators retranslated Moyes' books to

9 The Kite Runner is written by Khaled Hossein, an Afghan American author (2003).

${ }^{10}$ Pauline Sara Jo Moyes, born in 1969, is an English romantic novelist. Her famous novels Me Before You and After You are (re)translated in Persian. Her works were introduced to an Iranian readership by Maryam Meftahi. 
enter the literary translation field, but Meftahi is recognized as the pre-eminent specialist translator of Jojo Moyes in the Iranian book market.

Similar views have been shared by other translators. Shaghayegh Ghandhari admits that she is reluctant to accept retranslation offers from publishers. She explains her previous willingness to produce retranslations as a result of being unaware of the pre-existing translations:

$$
\begin{aligned}
& \text { من معمولا يِينهاد ناشرها را براى بإزترجمه نمى يذيرم. شله كتابي رو ترجمه كردم و بعل فهميدم }
\end{aligned}
$$

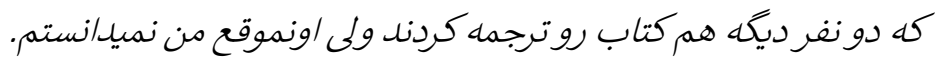

I usually do not accept publishers' retranslation offers. Once I translated a book and, later, I happened to discover that two other translators had previously translated it. I did not know about this at the time of translating. (Ghandhari)

Senior translators in the literary translation field confidently defend their retranslations. The translator of Saramago's novel Blindness (1995), Amraee, explains his decision to retranslate the novel by expounding that his retranslation is closer to the author's style of writing (Amraee). Amraee stoutly defends his retranslation of the novel, and openly acknowledges previous translations of the work:

$$
\begin{aligned}
& \text { درباه بازترجمه كورى هم من هر جايى در مورد ترجمه خودم صحبت كردم حتما اشاره كردمكه }
\end{aligned}
$$

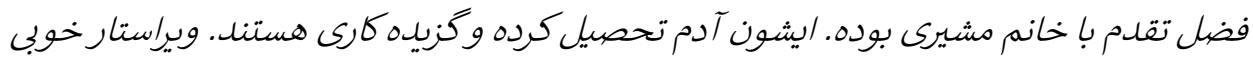

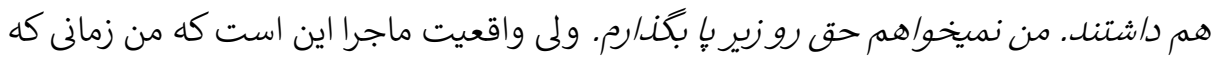

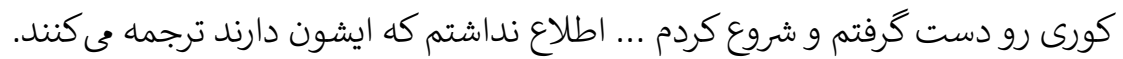

As for my retranslation of Blindness, wherever I mentioned my translation I acknowledged its previous translator, Ms Moshiri, who is an educated, discerning person. Her translation has also been edited by an adept editor. I want to be fair. The point is that by the time I started translating Blindness, I did not know that she had already been translating the book. (Amraee)

By conceding the high competency of the previous translator, Amraee demonstrates his own trustworthiness. He also reviewed another translation of the book performed by Mehdi Ghabraee, praising his competency and, in doing this, secures and enhances his own among the circle of translators. At the same time, Amraee simply acknowledges that he was unaware of previous translations.

In response to my question about why he retranslated a book on the history of art, Mohammad Nabavi revealed that he was unaware that another translator was translating the same book. Once he knew, he decided to release his translation later. As Nabavi explains: 


$$
\begin{aligned}
& \text { بعل /ز إيان ترجمه ى يه كتاب متوجه شلدم مترجم ديكرى هم اونو كاركرده. هون به هو هر حال }
\end{aligned}
$$

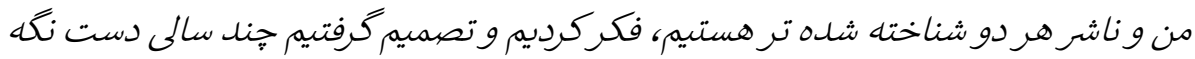

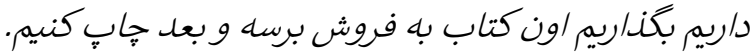

when I finished translating a book, I found that another translator had also translated the same book. The publisher of my translation and I decided to wait for a few years and allowed the other translation to sell as much as possible. Then, we published my translation of the book. The reason is that, comparatively, my publisher and I are more recognized. (Nabavi)

As the statement shows, Nabavi is confident that his trustworthy position among readers and in the literary translation field of Iran secures the sales of his translation even if released later.

The translators' views on retranslations provided here show that it is the social status of the translators in question that determines and justifies the production and reception of multiple translations in Iran. Based on the cases of Amraee and Nabavi, it seems that senior translators' motivations to retranslate are less likely to be interpreted by their readers as opportunistic. ${ }^{11}$

\section{Case Study: Retranslations of Animal Farm}

In this section, I discuss four retranslations of Animal Farm (Orwell 1945). The novella has enjoyed approximately one hundred Persian translations since 1979 and is a notable example of the practice of retranslation in Iran. The first Persian translation of AF appeared in 1965. After the Islamic Revolution of 1979, and between 1980 and 1984, four different retranslations of the book appeared. This surfeit seems to be due to the lack of a firm copyright law. Seventy-seven retranslations of AF were published after 2010 (see figure 1).

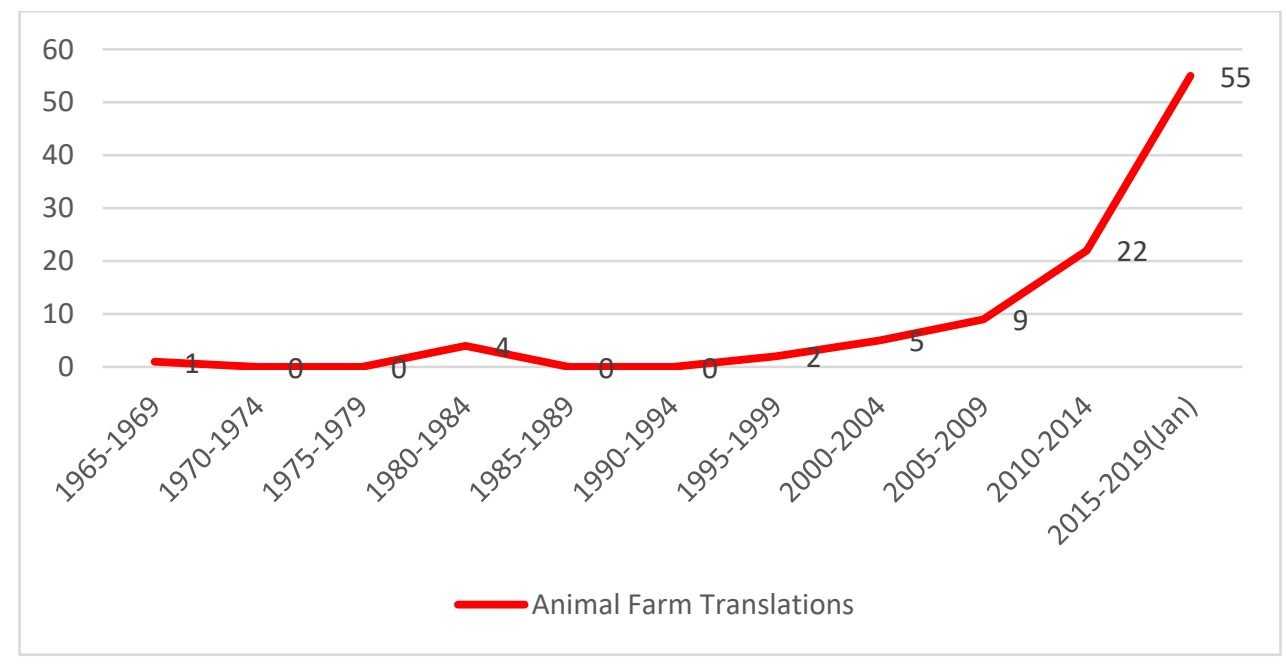

Figure 1: Trend in AF retranslations since 1969

\footnotetext{
${ }^{11}$ Reception of retranslations in Iran is thoroughly investigated in the author's doctoral dissertation: See Saeedi 2020.
} 
Figure 1 shows that retranslations of AF are active, in particular after 2010. Pym points out that, in the case of active retranslations, the causes are "far closer to the translator" (Method in Translation History, 83). In this case, then: who are the translators? Of the 97 translators, 72 are either amateur or early-career literary translators (see figure 2). ${ }^{12}$ The track records of the early-career translators show that they are mainly inclined to retranslate popular books and they are mostly commissioned by newly established or less recognized publishers.

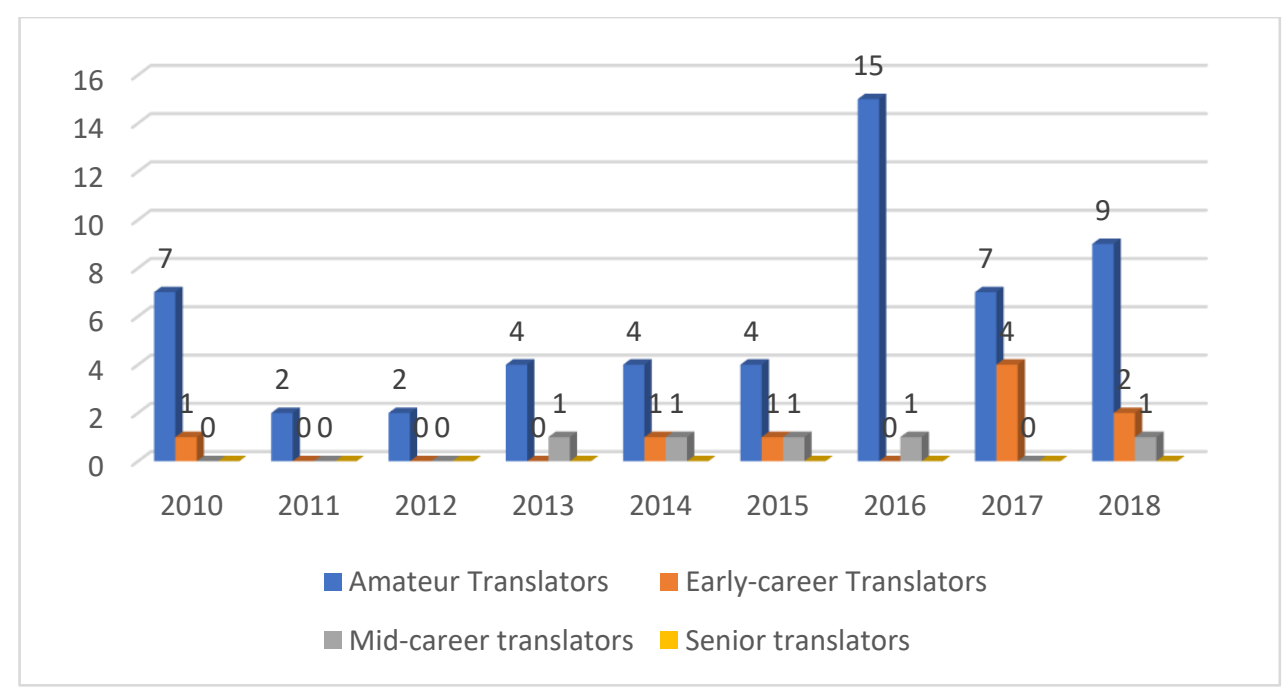

Figure 2: AF translator professional status

Several reasons motivate AF's retranslations. This includes the short length and simple prose of the novella, which makes AF a safe choice for amateur translators, and the novella's political content, which allows for the circulation of restricted discourses in Iran's literary translation field (see the case of Shahab Habibi below). For publishers, it is risky to invest in translation of a new work by an amateur translator as amateur translators are generally less familiar with publishing policies for a literary book in Iran. Besides, books with higher numbers of retranslations obtain publishing permits more easily than would newly translated books (Kaghazchi). Another reason for amateur translators to carry out retranslations is that such practitioners do not necessarily need to possess a high translation competence. There is the possibility of copying previous translations, applying minor modifications, and presenting them to the market as new translations. The basic level of visibility, that is, having their name on a translated book, serves as a non-economic incentive for amateur translators. ${ }^{13}$

From the perspective of the interviewees, the motivation behind high numbers of retranslation for AF is economic capital. For instance, Arbabi states:

\footnotetext{
12 These data are collected from the National Library of Iran database. I first looked for Persian titles of AF. Then, I recorded translators' biodata. Accordingly, I searched translators' names to identify how many books they had translated before translating AF.

${ }^{13}$ In Iran, translators' names are always printed on the front cover of translated books. This issue is thoroughly investigated in my PhD dissertation (Saeedi 2020).
} 


$$
\begin{aligned}
& \text { بعضا مترجم هاى مبتلى سراغ /ين كارمى رونل. /ين نشونه ى هيست؟ ... بيشنهاد بازترجمه /ز }
\end{aligned}
$$

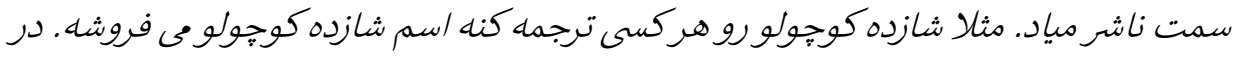

$$
\begin{aligned}
& \text { نتيجه ديكه براش كيفيت مهم نيست. }
\end{aligned}
$$

Sometimes, amateur translators tend to retranslate such works. What does it tell us?...publishers offer retranslations. For instance, no matter who the translator is, The Little Prince, is always profitable for the publisher. Therefore, these publishers are not concerned with the quality of translations. (Arbabi $)^{14}$

Amateur translators are either not paid or poorly paid (interviews, July-September 2017). Therefore, for newly established publishers AF's retranslation cultivates economic capital. For its amateur translators, it is a pathway to enter the literary translation field and build a track record.



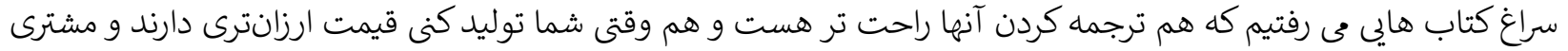

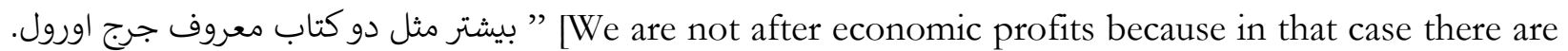
books that are easy and cheap to retranslate and, at the same time, have a vast readership, such as Orwell's books] (Saghravani). Hence, the retranslations of such novels are associated with profitdriven motivations in the literary translation market as well as the early-career translator's quest for visibility.

\section{A Paratextual Analysis}

In this section, I discuss paratexts of four active retranslations of AF. They are selected based on the abundance of paratextual materials and the availability of the books on the market. The retranslations under examination here are conducted by a senior translator, Homayoun Nourahmar (1983 edition); a mid-career translator, Ahmad Kasaeipour (2011); an early-career literary translator, Shahab Habibi (2015); and by a team of amateur translators: Pari Ghayouri and Hamidreza Ghayouri (2018).

The first retranslation of AF, in 1983, was performed by Nourahmar, a recognized Iranian literary translator. I use this retranslation to demonstrate how motivations for retranslating AF have changed over the decades. The paratext of this retranslation signals closeness to the start text by offering a literal translation of the book title, compared to the first translation. The first translation of AF was entitled Qaliyih Hiyvānàt (Orwell 1965), literally translated as 'Animals' Bastion', while this retranslation is entitled Marra'iyih Hiyvanät or 'Animals' Farm' (Orwell 1983), which is closer to the start text's title. The preface of the book illustrates Nourahmar's knowledge of English literature through comparing Orwell's style of writing to that of Jonathan Swift. ${ }^{15}$ Hence, it seems, similar to the

${ }^{14}$ Le Petit Prince [The Little Prince] was written by French author Antoine de Saint-Exupéry (1900-1944).

15 Jonathan Swift (1667-1745), known as Isaac Bickerstaff, was a leading Anglo-Irish prose satirist. For more see: https://www.britannica.com/biography/Jonathan-Swift. (access date: 10 May 2020). 
senior translators that I interviewed, Nourahmar's aim is to offer a more accurate translation of the start text.

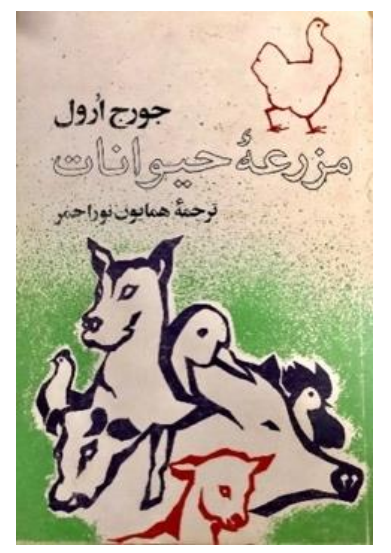

Figure 3: Mąra'iyih Hiyvānät, front cover, translated by Homayoun Nourahmar

Five categories of footnotes are identified: explanation of figures of speech, transliteration of proper nouns, conversion of measurement units such as yard and bushel, English equivalents of translated noun phrases such as Whiter Wool Movement, and clarification of untranslatable words. These transliterations and further explanations signal accuracy in the translated text. Having a trusted translator, this retranslation, by signalling closeness to the start text, legitimizes its presence.

Further retranslations of Animal Farm, which I will discuss shortly, share the following feature: they are all published after 2010, hence, they are produced in a state of competition. The retranslation of AF by Kasaeipour has been published in two different editions: medium octavo and pocket size, in 2011 and 2013 respectively, with different pricing and print-run (Orwell 2011). This retranslation is presented as being translated from a new start text - the edition released for the fiftieth anniversary of the book (Orwell 1996). Therefore, they signal that the start text is a different one compared to the previous retranslations. This may seem to be a fair justification for a new retranslation of the book. Figure 4 shows the front cover of AF's retranslation by Kasaeipour (Orwell 2011).

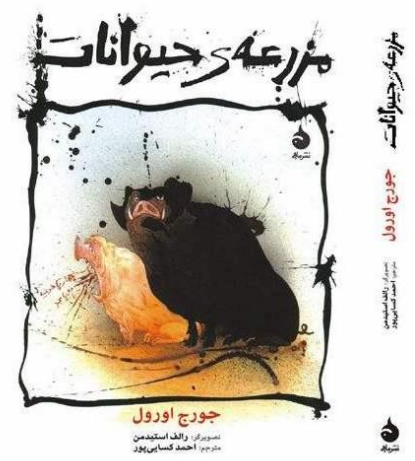

Figure 4: Front cover of AF, translated by Kasaeipour 
The front cover and in-book illustrations are copies of AF's new edition for the fiftieth anniversary of the book. Using book covers identical to the claimed new start text suggests that the translator and publisher negotiate trustworthiness of the new published translations with prospective readers. However, the hallmark of this start text is Orwell's preface "The Freedom of the Press" in which he criticizes the ethics of journalism (Orwell 1996). Either this preface was removed from Kasaeipour's retranslation in the publishing process, or the claim of using the new start text is false and was just used to promote and justify the new retranslation. Either way, they, Kasaeipour and Nashr-e Maahi, secured their symbolic capital. The octavo medium size, with an ornamental packaging, was published in 2011 and was last reprinted in 2013. The pocket size has been reprinted 9 times since 2014. The pocket-size version is cheaper compared to the octavo medium. This seems to be a strategy used by the publisher to increase the novella's sales.

The content of AF, which allegorically represents living under a dictatorial regime, serves as a platform for opposing voices. This is the case with the next retranslation of AF by Shahab Habibi (Orwell 2015). This retranslation is the most outspoken version in terms of the translator's intention for retranslating the book. In this case, the author's intention for writing the novella is also retranslated. Habibi attempts to connect the content of the book with his own experience in his country. Therefore, the translator not only retranslates the book textually, but also socially, through the extensive use of paratextual materials.



Figure 5: Front cover of AF, translated by Shahab Habibi, published by Chelcheleh

The preface of this retranslation follows the intention behind the front cover. To reveal his own interpretation of the book to the readers, Habibi establishes his persona as a reliable and educated person. In the dedication page, for instance, Habibi says “ ترجمه /ين /ثر راتقديم مى كنم به مادرم ناهيد، كه /ز "كودكى تا كنون، روزى را بلدون آموختن از اونكندرانده /م. [I dedicate the translation to Nahid, my mother, with whom I haven't passed a day without learning] (in Orwell 2015). Habibi's preface mainly has a hermeneutical function in the sense that it highlights "certain aspects or qualities, mediating relevant contexts, instructing the understanding or interpretation" (Batchelor 160). For instance, in his preface, Habibi attempts to unravel the allegorical meaning of the text and forground his own interpretation which, following Batchelor, widens readers' "interpretive options" (160). Habibi is open about his 
ideological motivations behind retranslating the book and makes attempts to raise the reader's اين بار انكار تازه داشتم لايه هاى ديكر داستان را " awareness of the metaphorical content of AF by saying that

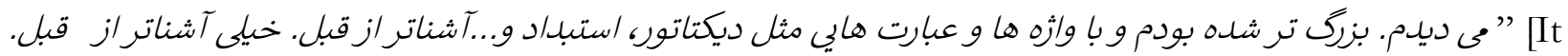
was like I was seeing other layers of the book. I was a grown-up and more familiar with words such as dictator, despotism and ... more familiar than before] (Habibi 6). Habibi continues:

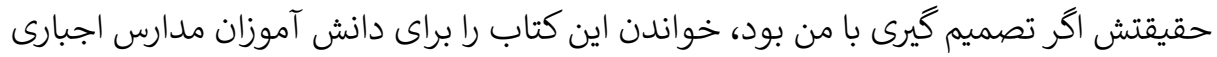

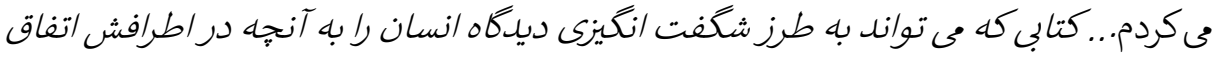

$$
\begin{aligned}
& \text { مى افتل تغيير دهل. }
\end{aligned}
$$

If I was to decide what should be taught at school; I would make it compulsory for students to read this book ... this book has great potential to make people rethink their surroundings. (7)

Regarding his accuracy in translation, Habibi adds that he has taken a university course to learn about the technical equivalences in Persian, but again he asks readers: " زياد سخت نكيريي كه بازهم حرف "حيز ديكرى /ست "[take it easy as the story is not about these things] (8). While Habibi aims at reinforcing his own political agenda through retranslation of the text, he still finds it necessary to earn readers' trust.

I close this section by considering the retranslation of AF by Hamidreza Ghayouri and Pari Ghayouri (Orwell 2018). This case reveals how contextual factors contribute to the emergence of retranslations and unveils the possible reasons behind the increasing distrust toward retranslation. The front cover of the retranslation displays several trust-signalling strategies. There are two titles printed on the front cover: Qal'iyib'i Hiyvānàt in a larger font, and Marra'iyih Hiyvanāt in a smaller font as a subtitle in parentheses (see figure 6, the front cover on the left). Also, from the information on the front cover, we learn that the book is a bilingual version of the novella.

The translators' and publisher's surnames indicate the family relationship between them. The same translation was re-published in the same year by two further translators, Ghazaleh Ghayouri and Nazanin Ghayouri, apparently all members of the same family (see figure 6, the front cover on the right). These retranslations have the same book covers and the same prefaces-only the names of translators have been changed, as figure 6 illustrates. Publishing in this case seems to be a family business. 


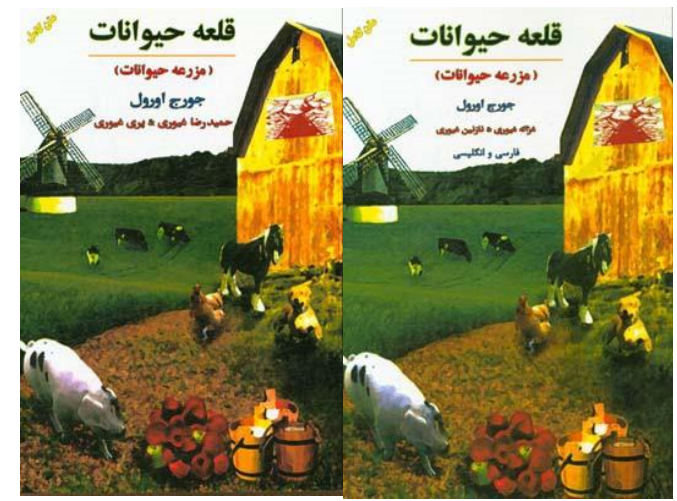

Figure 6: Front covers of two different translations of AF

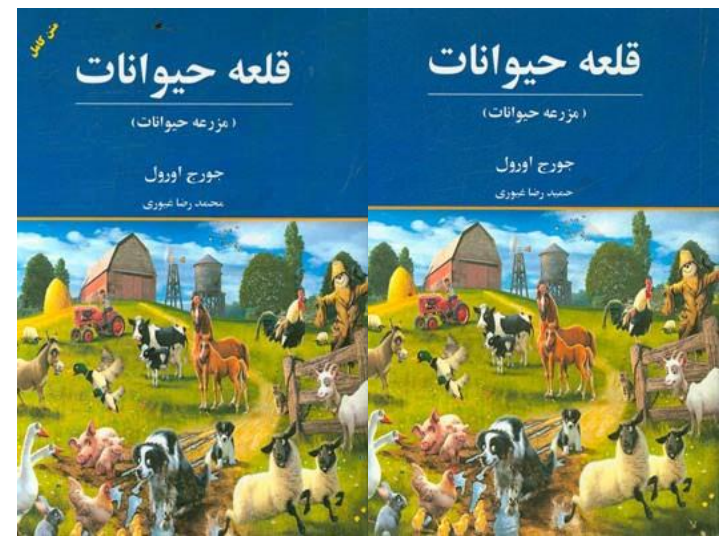

Figure 7: Front covers of two different translations of AF

Hamidreza Ghayouri had already translated and published AF solo in 2016 with another publisher, Rastin, whose director is Hasan Ghayouri (figure 7, on the right). ${ }^{16}$ Again, this retranslation has a doppelganger with a different translator's name, Mohammadreza Ghayouri (Orwell Animal Farm [Qal'iyib'i Hiyvānat]) published by Yung publishing (figure 7, on the left). Each of these four retranslations is published by a relative, as the surnames suggest.

Clearly, translators seek to gain visibility by having their names printed on the front covers, but the small number of copies per print-run, 200, suggests another possible explanation. In Iran, publishers must renew their publishing business licence biennially and provide the Ministry of Culture and Islamic Guidance (MCIG) with a business report which proves that they are actively working. To be eligible for renewing their publishing business licence-that is, the license which allows one to work as a publisher in Iran-Iranian publishers need to publish four books per year which should be "preferably first print" (article 15 in Principles of Issuing Publishing House Licence). ${ }^{17}$ This would allow publishers to get extension for their business licence. For newly-established publishers, it is a

\footnotetext{
${ }_{16}$ Retrieved from https://www.chaponashr.ir/rastin (access date: 26 October 2019)

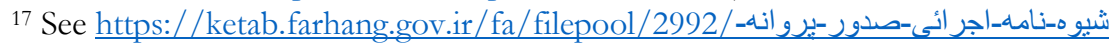
نش: redirectpage $=\% 2 \mathrm{ffa} \% 2$ fregulations $\% 2$ fregulations1 (access date: 20 May 2020).
} 
financial risk to publish a book without any certainty about market reception. Therefore, publishing the same book under different names not only diminishes the financial risk of publishing a first-print book, but also makes them eligible to continue their publishing business. In the example of the Ghayouri's retranslations, the publications are all first print and are published with different translators' names. In these cases, therefore, retranslation seems to be, partially, a strategy for fulfilling the criteria set by the MCIG in order for their publishing business to survive.

The paratextual analysis of retranslations offered in this section reveals that there are several incentives for translators and publishers. As the evidence suggests, retranslation in Iran does not follow a linear progression in terms of quality and reliability. Mid-career and senior translators are most concerned with justifying their retranslation practice by foregrounding the novelty of their work, whether by choosing a different title, foregrounding a different theme, or offering a more reliable edition. The first discussed retranslation, Nourahmar's, covertly addresses the inadequacy of the first translation. The last three retranslations were published within a short period of time with a variety of strategies that challenge the previous translations: Kasaeipour's multi-version edition, Habibi's activist angle and the Ghayouri's collaborative translation.

\section{Concluding Remarks}

Drawing on Bourdieu's concepts of capital and field as well as Rizzi, Lang, and Pym's concept of trustsignalling, this paper aimed to shed light on a complex series of motivations informing the substantial production of retranslations in contemporary Iran. Evidence suggests that retranslations are in most cases a combination of socially and financially motivated tasks. Retranslation is rewarding, but at the same time an unsavoury practice for translators depending on how trustworthy the intercultural mediators are. This is determined by their position in the literary translation field.

Collaboration between senior/mid-career translators and established publishers results in "institutional trust," which means readers "do not need to know professionals directly: they have enough confidence in the profession" and the standard of the product that they receive, as Rizzi, Lang and Pym remind us (13). Therefore readers, without questioning the motivations behind retranslations, tend to accept the emergence of a new retranslation. For publishers, commissioning trusted translators bolster their claim that only they are able to offer reliable retranslations.

Producing retranslations under such a state of intense competition seems to be a profitable trade for amateur translators: a pathway to enter the literary translation field and gain quick recognition. Although they are usually underpaid for their work, retranslation is an opportunity to build their persona and their track record. For newly established and unrecognized publishers, retranslation offers much-needed economic capital from the sales of popular books as demonstrated in the case of AF translated by the Ghayouri family. Also, it seems in the case of active retranslations that major contextual factors, such as the near-total lack of enforcement of (inter)national copyright laws and conventions, play a key role. 
This paper suggests that retranslation can be a response to the translator's or publisher's aspiration to compete for a significant cultural role in their society. Even if this practice comes with financial risks, the potential gain in cultural capital outweighs such dangers. The translators' and publishers' perceptions gauged from the interviews discussed here are that retranslation provides Iranian readers access to restricted ideas and narratives. Retranslation in Iran is a distinctively social phenomenon. 


\section{REFERENCES}

Alvstad, C. and A. A. Rosa. "Voice in Retranslation: An Overview and Some Trends." Target, vol. 27, no. 1, 2015, pp. 3-24, Scopus, doi:10.1075/target.27.1.00int.

Amirdabbaghian, Amin and Krishnavanie Shunmugam. "An Inter-Semiotic Study of Ideology on the Book Covers of Persian Translations of George Orwell's Animal Farm." Ilha do Desterro, vol. 72, no. 2, 2019, pp. 225-243.

Amraee, Asadollah. Interview. By Samira Saeedi. 17 August 2017.

Ankit, Ahmed and Said Faiq. Agency and Patronage in Eastern Translatology. Newcastle upon Tyne : Cambridge Scholars Publishing, 2015.

Arbabi, Mohammadreza. Interview. By Samira Saeedi. 02 July 2017.

Azadibougar, Omid and Esmaeil Haddadian-Moghaddam. "The Persian Tradition." A World Atlas of Translation, edited by Yves Gambier and Ubaldo Stecconi, John Benjamins Publishing Company, 2019.

Austen, Jane. Pride and Prejudice. T. Egerton, Whitehall, 1813.

Batchelor, Kathryn. Translation and Paratexts. Routledge, 2018.

Berman, Antoine. « La Retraduction Comme Espace De La Traduction. » Palimpsestes, vol. 4, 1990, pp. 1-7.

Bistué, Belén. Collaborative Translation and Multi-Version Texts in Early Modern Europe. 2013. Collaborative Translation and Multi-Version Texts in Early Modern Europe.

Bourdieu, Pierre. In Other Words: Essays Toward a Reflexive Sociology. translated by Matthew Adamson, Stanford University Press, 1990.

. "The Forms of Capital." Cultural Theory: An Anthology, edited by Imre Szeman and Timothy Kaposy, Wiley-Blackwell, 2011, pp. 81-93.

Brownlie, Siobhan "Narrative Theory and Retranslation Theory." Across Languages and Cultures, vol. 7, no. 2, 2006, pp. 145-170.

Camus, Albert. L'étranger [the Stranger]. Gallimard, 1942.

Chesterman, Andrew. "A Causal Model for Translation Studies." Intercultural Faultlines, edited by Maeve Olohan, ST.Jerome, 2000, pp. 15-27.

- "Hypotheses About Translation Universals." Claims, Changes and Challenges in Translation Studies, edited by Gyde Hansen et al., John Benjamins, 2004, pp. 1-14.

- Memes of Translation: The Spread of Ideas in Translation Theory. Amsterdam; Philadelphia : John Benjamins Publishing Company, [2016]. Revised edition., 2016. Benjamins Translation Library. Est Subseries: Volume 123.

Deane-Cox, Sharon. Retranslation: Translation, Literature and Reinterpretation. Bloomsbury, 2014.

Flaubert, Gustave. Madame Bovary. Michel Lévy Frères, 1857.

Ghandehari, Shaghayegh. Interview. By Samira Saeedi. 25 July 2017.

Ghane, Ali. "Barayi Trajomih Kārhayi Porforush Mosabiqih Bi Rāh Oftadih! [a Competition for Retranslating Best-Sellers!].” Interview by Maedeh Mortazavi, Iran Book Agency, Ibna, 13 
February 2018, p. Literature and Art. http://www.ibna.ir/fa/longint/256724/-ترجمه-كرهاى يرفروش-مسابقه-راه-افتاده

Goethe, J. W. von. "Übersetzungen." Noten Und Abhandlungen Zum Besseren Verständnis Des WestÖstlichen Divans, 1819.

Haddadian-Moghaddam, Esmaeil. Literary Translation in Modern Iran: A Sociological Study. John Benjamins, 2014.

Hosseini, Khaled. The Kite Runner. Bloomsbury, 2003.

Hosseinkhani, Leila. Interview. By Samira Saeedi. 19 July 2017.

Hugo, Victor. Les Misérables. A. Lacroix, Verboechoven \& Cie, 1862.

Kaghazchi, Kaveh. Interview. By Samira Saeedi. 02 May 2018.

Karimi Behbahani, Sayyed Mohammad. "Bāztarjomihā Byshtar Sodāgary Dar Bāzāri Nashr Ast [Retranslation: A Profit-Driven Practice in the Publishing Market]." Islamic Republic News Agency, 17 May 2019.

Meftahi, Maryam. Interview. By Samira Saeedi. 15 August 2017.

Nabavi, Mohammad. Interview. By Samira Saeedi. 19 July 2017.

Nabipour, Samin. Interview. By Samira Saeedi. 16 July 2017.

Obama, Michelle. Becoming. Crown, 2018.

Orwell, George. 1984. Harcourt, 1949.

—. Animal Farm. 50th anniversary edition, Harcourt Brace International, 1996.

—. Animal Farm [Maæra'ib'i Hiyvannät. translated by Homayoun Nourahmar, Nashr-e Marzban, 1983.

- Animal Farm [Masraizin Hiyvänät]. translated by Hamidreza Ghayouri and Pari Ghayouri, Ghayouri, 2018.

—. Animal Farm [Masräyih Hiyvänät]. translated by Shahab Habibi, Chelcheleh, 2015.

—. Animal Farm [Ma:ra'iyih Hiyvānāt]. translated by Ahmad Kasaeipour, Maahi, 2011.

—. Animal Farm [Qal'iyih'i Hiyvānät]. Yung, 2018.

- Animal Farm: A Fairy Story. Harcourt, 1945.

—. Qaliyibi Hiyāanat [Animal Farm]. translated by Amir Amirshahi, Pocket Books, 1965.

Paloposki, Outi and Koskinen, Kaisa. "A Thousand and One Translations: Revisiting Retranslation." Claims, Changes and Challenges in Translation Studies, edited by Gyde Hansen et al., John Benjamins, 2004, pp. 27-38.

Pokorn, Nike K. Post-Socialist Translation Practices: Ideological Struggle in Cbildren's Literature. John Benjamins, 2012.

Pym, Anthony. Exploring Translation Theories. Routledge, 2014. - Method in Translation History. vol. null, 1998. Null.

Rizzi, Andrea. "Editing and Translating Pliny in Renaissance Italy: Agency, Collaboration and Visibility." Renaessanceforum - Journal of Renaissance Studies, vol. 14, 2018, pp. 117-138. et al. What Is Translation History? A Trust-Based Approach. Palgrave Macmillan, 2019.

Rohaniyoun, Pirouzeh. "Negāhy Bi Tarjūmiāyi Mūvazy Āsāri Khariji Dar Dahiyih Akhyr: Qisiyih Nā Mūkarrari Tarjūmihāyih Mūkarrar [a Review of Parallel Translations During the Last Decade: The Infrequent Story of Frequent Retranslations]." Khabar Online, Khabar Online, 2009. 
Saeedi, Samira. The Role of Translators in Contemporary Iran: New Perspectives on Collaboration, Retranslation and Visibility. The University of Melbourne, PhD dissertation, 2020.

—and Sayyed Mohammad Karimi Behbahani. "A Sociologgical Approach to Translation: Translation and Asymmetrical Exchange of Cultural Capital." Translation Studies Quarterly, vol. 13, no. 52, 2016.

Saghravani, Lotfallah. Interview. By Samira Saeedi. 03 September 2017.

Saint-Exupéry, Antoine de. Le Petite Prince. Gallimard, 1943.

Sand, George. La Mare Au Diable. 1846.

Tahir Gürçaglar, Şehnaz. "Retranslation." Routledge Encyclopedia of Translation Studies, edited by Mona Baker and G Saldanha, Routledge, 2009, pp. 232-234.

Vahid Dastjerdi, Hossein and Amene Mohammadi. "Revisiting "Retranslation Hypothesis': A Comparative Analysis of Stylistic Features in the Persian Retranslations of Pride and Prejudice.” Open Journal of Modern Linguistics, vol. 3, no. 3, 2013, pp. 174-181.

Wolf, Michaela. "Introduction: The Emergence of a Sociology of Translation." Constructing a Sociology of Translation, edited by Michaela Wolf and Alexandra Fukari, John Benjamins, 2007, pp. 1-36. 